\title{
Mediation - an alternative to litigation in medical malpractice
}

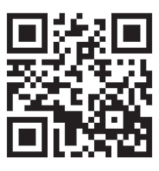

$\therefore$ may we live in a world without lawyers and court cases ...' (Confucius)

Interestingly, by the end of the communist era in China there were only 10000 lawyers serving the needs of that entire nation. But that did not mean people were without justice. Confucius said a lot of things, and his take on the legal side of life was spot on. Adherence to Confucianism, with the core values of 'perfect virtue, middle ground and authority admiration [respect], is still part of Chinese culture today. ${ }^{[1]}$ Positioned in every community were people whose task it was to resolve conflict as it arose. Reportedly, there was one counsellor for every 100 souls throughout the country. While one can speculate as to how these disputes were resolved, what is interesting is that the community developed a system that essentially ensured justice for all.

How is it that we have allowed ourselves to end up where we are? The evolution of the justice system in the Western world seems to have taken a very different path to that of the Chinese. Our legal system has focused firmly on applying the 'law', and not necessarily on seeking justice. An $S A M J$ editorial last year ${ }^{[2]}$ outlined very clearly the dilemma currently facing doctors over much of the world. Two publications in this issue, an editorial by Howarth et al. ${ }^{[3]}$ and an article by Roytowski et al., ${ }^{[4]}$ further underline the magnitude of the problem. Through our legal system, the cost of doctors protecting themselves from possible legal action has reached breaking point, as evidenced by the threat that obstetricians might abandon the practice of obstetrics becoming an ever-increasing reality.

The problem does not affect doctors alone. For healthcare institutions, in particular those managed by the state and 'covered' by taxpayers' money, the position is just as dire. The Gauteng government has recently settled claims in excess of R2 billion, with about as much still pending. That these funds were destined for the health budget underscores the crisis in the public sector as well.

So how did we get here? There are numerous cost drivers that are taking healthcare beyond our reach. An easily identifiable and prominent cost-driving factor can be attributed to the law, or rather the implementation thereof. Khan et al. ${ }^{[5]}$ have suggested, somewhat pointedly, that apart from the role played by the changing expectations of the public, a growing legal services industry plays an active role in the cost escalation. Fear of litigation fuels cost-inefficient defensive practice. The upward spiral of escalating legal fees and costs is indicative of a 'dispute' resolution process that we can no longer afford. This process has affected the very nature of the healthcare we provide. The profession, once characterised by the generosity of altruism, has, with the passage of time and a multitude of events involving a few, become transformed into a fearful and defensive band of practitioners constantly watching their backs. A recent survey of orthopaedic surgeons in the USA disclosed that $96 \%$ of participants practised defensive medicine. ${ }^{[6]}$ It is estimated that the cost of defensive orthopaedic practice in the USA is around $\$ 2$ billion per year, while Mello et al. ${ }^{[7]}$ reported this to have reached $\$ 45$ billion in 2010. What was once a dilemma is now a crisis.

Our legal structure is based on the 'tort' system, meaning that in terms of the law of delict, if patients suffer as a result of failure of a hospital or a doctor to provide reasonable care due to negligence, compensation can be sought. ${ }^{[8]}$

In an editorial in the $S A$ Orthopaedic Journal, ${ }^{\left[{ }^{[]}\right.}$I presented the arguments against litigation as the appropriate oversight system, citing that it is expensive, that most of the money spent accrues to the legal teams, and that it is cumbersome and time consuming without necessarily reaching the desired goal, which, as Confucius would have put it, should be fairness in righting the wrong. In addition, litigation means that the plaintiff will only succeed in the event of negligent practice being proven against the practitioner, but enjoys no compensation or benefit when an inherent or unavoidable error has occurred. This is not the case when alternative dispute resolution methods are employed.

The call for change is strong. But what are the alternatives to the litigation system under which we operate? Arguments for changes in the tort system are being heard around the world, such as a shift of liability from physician to enterprise, while momentum is gathering for the introduction of health courts, for no-fault compensation, and towards arbitration and mediation. There are two core factors informing this shift. Firstly, there is an increasing acknowledgement that not every complication or error is 'avoidable. We work in systems that are frequently beyond our control and have boundaries that are not ideal. Innovations to minimise the 'human factor' are being usefully introduced, such as the 'surgical safety checklist'. Introduced under the auspices of the World Health Organization to reduce system errors for patients undergoing surgery, this system of checks and balances to eliminate errors ensures accurate communication and interaction with all involved in the management of patients. ${ }^{[10]}$ Secondly, a major advantage of some of the alternative systems proposed to replace litigation is that a great deal of the money spent on the legal process will be directed at redressing the wrongs where help is needed, and that ultimately this benefit accrues to the healthcare system rather than disappearing down a legal drain. The plaintiff is more likely to derive benefit without falling foul of legal technicalities.

Sohn ${ }^{[11]}$ suggests that ideally whatever system operates should ensure appropriate compensation for the medical injury and correctly identify the error, and that knowledge gained from the adverse effects should help to build systems that eliminate errors. This is not always the case with litigation, especially disputes settled on the courtroom steps.

The major problem is the disjuncture between the costs associated with defensive practice, mounting a claim and the defence thereof, and how much is directed to restitution of what caused the problem in the first place. As in the USA, we have no repository for medical malpractice claims, so determining the actual amounts directed to the legal process is a difficult task. For the USA, this is estimated to be in the order of $2.4 \%$ of the total national healthcare expenditure. ${ }^{[12]}$ Only about $30-45 \%$ of money involved in the settlement of a claim finds its way to the claimant. ${ }^{[13]}$ Obviously healthcare would be much better off if the money spent on the legal process was channelled instead into the healthcare system itself.

It is this realisation that has led to the pursuit of alternative dispute resolution $(\mathrm{ADR})$ mechanisms. Arbitration and mediation are two possibilities that may serve this purpose.

Of these two, mediation is perhaps the most effective. The essence of mediation is that it involves the two parties communicating through a facilitator. The complainant or aggrieved party has an opportunity to define and address the complaint to the respondent, while the respondent has an equal chance to explain the events that led to it. A trained mediator facilitates the process, guiding both parties to a point of mutual agreement or acceptance.

The majority of complaints against healthcare workers or institutions are issues that arise out of miscommunication. Such issues are ideal for the mediation process. While most complaints involving negligence or malpractice are also amenable to mediation, in certain instances the nature of the injury or offence is of such a nature that official censure will need to be applied. Such penalty or censorship can only be effectively instituted by the relevant governing 
body, namely the Health Professions Council of South Africa, or the law courts, where a full legal inquiry into such conduct needs to be undertaken. In medical matters, as with commercial civil suits, only a minority of cases truly require the full process of the law.

The estimated cost of mediation is an order of magnitude less than litigation, both financially and in terms of time. This financial cost saving will directly benefit the healthcare system. Medical malpractice insurance will diminish significantly, as the associated costs of litigation, namely the court and 'silk' costs, will not apply. What is paid will to a large extent cover the direct costs or costs of restitution that may arise out of malpractice or negligence.

At present the USA, Canada and the UK have embraced mediation for settling medical disputes, which are increasingly being resolved in this fashion. The courts in Florida, USA, are duty bound to first refer the complaint for mediation; if this fails, litigation can proceed. In the 2013 Medical Malpractice Annual Report ${ }^{[13]}$ the mechanisms by which claims were settled are reported as $31 \%$ abandoned, $42 \%$ settled by parties, $15 \%$ court settled and $12 \%$ settled by ADR. Interest in alternatives to litigation is increasing: the SA government is showing great interest in ADR, and legislation has been passed to ensure that court-annexed mediation at magisterial level is in place by December 2014. For additional information on mediation, see http:// www.mediate.com

There is no doubt that we are in deep trouble. Our profession cannot be expected to continue along this path for much longer. With the assistance of a pinch of Confucianism, we have at our disposal very positive solutions to address this medicolegal crisis. The ball is in our court.

\section{Johan Walters}

Division of Orthopaedic Surgery,

Department of Surgery,

Faulty of Health Sciences, University of

Cape Town, South Africa

johan.walters@uct.ac.za

1. Qin G. The thinking way of Confucianism and the rule of law. Journal of Politics and Law 2008;1(1):68-72. [http://dx.doi. org/10.5539/jpl.vlnlp68]

2. Seggie J. The 'boom' in medical malpractice claims - patient could be the losers. S Afr Med J 2013;103(7):433. [http://

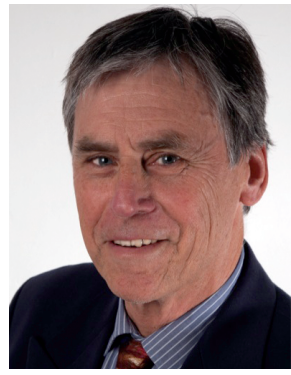
dx.doi.org/10.7196/SAMJ.7127]

3. Howarth GR, Goolab B, Dunn RN, Fieggen AG. Public somnambulism: Public lack of awareness of the consequences of increasing medical negligence litigation. S Afr Med J 2014;104(11):752-753. [http:// dx.doi.org/10.7196/SAMJ.8568]

4. Roytowski D, Smith TR, Fieggen AG, Taylor A. Impressions of defensive medical practice and medical litigation among South African neurosurgeons. S Afr Med J 2014;104(11):736-738. [http://dx.doi. org/10.7196/SAMJ.8336]

5. Khan IH, Jamil W, Lynn SM, Khan OH, Markland K, Giddins G. Analysis of NHSLA claims in orthopedic surgery. Orthopedics 2012;35(5):e726-e731. [http://dx.doi.org/10.3928/01477447-20120426-28]

6. Sethi MK, Obremskey WT, Natividad H, Mir HR, Jahangir AA. Incidence and costs of defensive medicine among orthopedic surgeons in the United States: A national study survey. Am J Orthop 2012;41 (2):69-73.

7. Mello MM, Chandra A, Gawanda AA, Studdert DM. National costs of the medical liability system. Health Aff 2010;20(9):1569-1577. [http://dx.doi.org/10.1377/hlthaff.2009.0807]

8. Coetzee L, Carstens P. Medical malpractice and compensation in South Africa. University of Chicago Law Review 2011;86(3):1263-1301.

Walters J. Medical malpractice litigation: Is there an alternative? SA Orthopaedic Journal 2013;12(3): 13. http://www.scielo.org.za/scielo.php? ?script=sci_arttext\&pid=S1681-150X2013000300001\&lng=en\&
nrm=iso (accessed 8 September 2014).

10. World Health Organization. WHO surgical safety checklist and implementation manual. www.who. int/patientsafety/safesurgery/ss_checklist/en (accessed 8 August 2014).

int/patientsafety/safesurgery/ss_checklist/en (accessed 8 August 2014).
Sohn D. Negligence, genuine error, and litigation. Int J Gen Med 2013;3(6):49-56.

11. Sohn D. Negligence, genuine error, and litigation. Int J Gen Med 2013;3(6):49-56.
12. Studdert DM, Mello MM, Gawande AA, et al. Claims, errors, and compensation payments in Studdert DM, Mello MM, Gawande AA, et al. Claims, errors, and compensation payments in
medical malpractice litigation. N Engl J Med 2006;354(19):2024-2033. [http://dx.doi.org/10.1056/ medical malpractice litigation. N Engl J Med 2006;354(19):2024-2033. [http://dx.doi.org/10.1056
NEJMsa054479]

3. Kreidler M. 2013 Medical Malpractice Annual Report. http://www.insurance.wagov/about-oic/commissioner-
reports/2009-present/documents/2013-med-mal-annual-report.pdf (accessed 14 August 2014). reports/2009-present/documents/2013-med-mal-annual-report.pdf (accessed 14 August 2014)

S Afr Med J 2014;104(11):717-718. DOI:10.7196/SAMJ.8851 